Received: 30.04 .2021$.

doi: 10.46763/JESPT211610041k

udc:37.018.43:004]:78

Revised: 11.05.2021.

Accepted: 22.05 .2021

\title{
DISTANCE TEACHING OF MUSIC ART WITH THE HELP OF ICT
}

\author{
Kristina Kern ${ }^{1}$ \\ 'Primary School Hinko Smrekar, Ljubljana, Republic of Slovenia \\ kristina.kern@guest.arnes.si
}

\begin{abstract}
Music art is a subject through which students get to know the folk tradition, get to know each other, become aware of each other's differences, differences. They strengthen the psycho physical and social development. It helps us improve our mental abilities and also strengthens us physically. In this paper, I would like to show a few lessons in the subject of music art, in which students will learn about difference and expand knowledge, deepen their awareness of diversity. In these timeswhen the world is changing radically (economy, health, public and cultural life, education), professionals in the field of education with the help of ICT equipment began to develop innovative ideas for working with our students, we began to build a new education system and training. We have introduced new learning approaches, methods, and techniques of teaching material through various applications and programs. I chose the MS Teams application to teach the material, where I prepared a special channel for students, which was secured and to which I added learning material every day, which we also processed and discussed at a video conference with my students. For example, in my posts I show a music art class where I show interactive work with my students. I prepared a Microsoft Power point forthe lesson, thus enabling students to learn remotely with the help of ICT. At the video meeting, we felt like we were in school.
\end{abstract}

Key words: music, percussion, long and short tones, difference, diversity.

\section{Introduction}

In this paper, I show how to conduct a distance lesson in the subject of art, where I tried toenable students to develop knowledge in this area, develop psychophysical abilities, a lot of movement, singing, spreading positive energy, and strengthening social relationships in a virtual way.

When working remotely, the students needed ICT equipment so that they could follow my explanation and then practice and consolidate themselves. The students participated, sang, danced and had fun all the time. In this way, we enabled the spread of positive energy even at a distance.

In addition, the students tried to get to know different songs of the world, as there are a lotof immigrant students in my class. This is how we learned about diversity and differentness. We got to know Macedonian, Chinese, Bosnian, Russian children's songs.

We first discussed the subject matter with the help of my explanation, then they got to knowthe songs of different parts of the world.

In Macedonian, we got to know the song "Duvna vetre razvigorče" and tried to understandthe lyrics. A student from Northern Macedonia also translated the text approximately. Everyone was happy. We learned that the text talks about the wind.

The purpose of this paper is to show that even at a distance we can succeed in upgradingthe understanding of difference, diversity and spreading folk tradition through the musical activities of different parts of the world. The goal, however, was for students to get to know their classmates from a different perspective, to get to know their culture through song and dance. 


\section{Theoretical starting points}

Music is a concept defined and explained in several ways. It is used to denote forms of entertainment, the contrast between speech and noise. We know it as an orderly and formedsequence of noises, tones, and the like, or as a social perception and a platonic ideal that originates from specific factors (Tajaknez, 2020).

Muršič (1993) says that music plays an important role in people's daily lives and that for some it is very essential for the formation of social identity. The judge says that it is importantfor a person's life and that it is a key thing in an individual's everyday life. It is presented as an art, a form of entertainment or the opposite of speech or noise. Through music, it is difficult todistinguish content from form and sound from its message. Wagner claimed to represent passion, love, and longing.

According to Muršič (1993), music is an activity that we express through singing, dancing,listening to music, as passive and active listeners, and spectators. Music is a part of the socialization process, which is expressed through education in the home or school environment.

Listening to and experiencing music works on us as a medicine, it works on our personalities, bodily functions, nervous system, and on stimulating imagination and thinking. He says that music education arouses joy and positive feelings towards music, forms a positive attitude towards Slovenian and world music culture and knowledge. In this way, he also learns about its significance and values of art (Uranjek, 1993).

The music curriculum allows us to learn about and teach music in a variety of innovative ways. Methods, techniques, and approaches are chosen by professionals based on various experiences, desires, and motivational affinities, which we want to spread and offer to our students (MIZŠ, 2011).

According to the curriculum, music appears in every culture, so we label it as a cultural phenomenon, which was also shown by the authors who researched this field. In humans, itexpresses a desire to create a sound environment, communication, and creativity. The subjectof music in primary school enables children to get to know and understand themselves inrelation to others and the web of connections between home, school, and the world. Throughmusic, we encourage self-discipline, creativity, aesthetic sensitivity, expression in variousfields and the spread of positive energy in the environment in which we operate (MIZŠ, 2011).According to the curriculum for the first educational period (MIZŠ, 2011), students learn to sing children's, folk and art songs in a group and independently relax and experience, learndifferent songs from the past and present, record adult interpretation, sing, listen loudly, quietly, slower, and faster implementation. In addition, while learning, they learn to show experience, deepen the elements of aesthetic song design, form a singing voice, deepen the reliability of singing and utterances. They learn to create and listen in music, and teachers evaluate this in the end (MIZŠ, 2011).

\section{Distance learning with ICT}

Based on theoretical background and general knowledge about music, we can say that students learn about their roots, folk tradition, know how to understand themselves and othersand enable them a broad understanding of classmates coming from Slovenia and other partsof the world.

We conducted the lessons remotely with the help of a Power point presentation, where wewanted to present musical and other concepts in the best way. In addition to explanations, thought patterns, hints, and links for more in-depth learning, a lot of pictorial material, we video teachers still added their personal note, our voice, to video meetings. It is still the teacher whoguides, guides, inspires, motivates, helps the student to develop a personal, life relationship to the material, phenomenon, problem...

The following is a practical example of performing work remotely via the MS Teams application and using ready-made sliders.

At the beginning of the lesson, we read the story of Hedgehog Max. Teachers pay close attention to tracking, reading with accents. When we read a story, we talk about the story through questions. 


\section{DOLGI IN KRATKI TONI V GLASBI}

\section{3. razred}
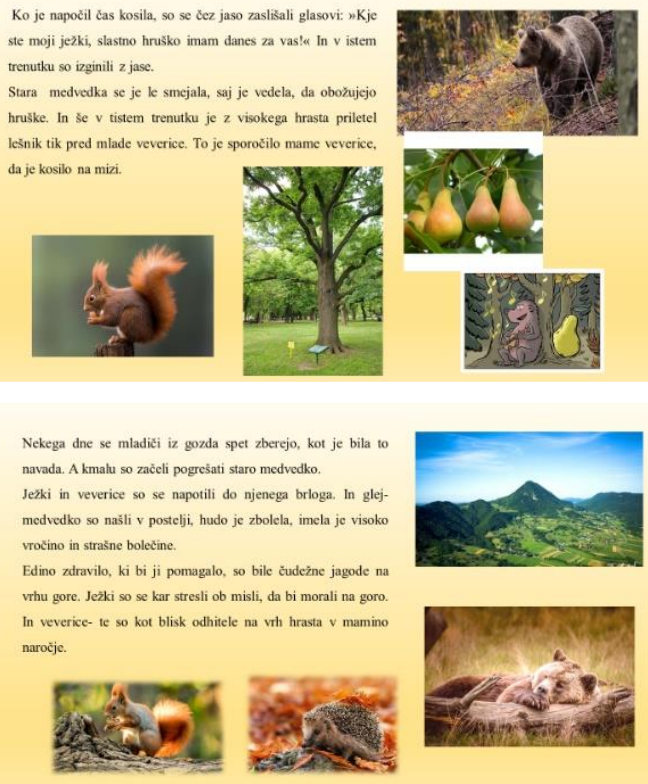

Picture 1

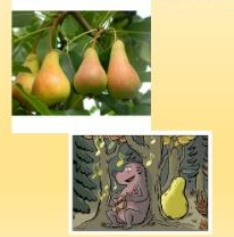

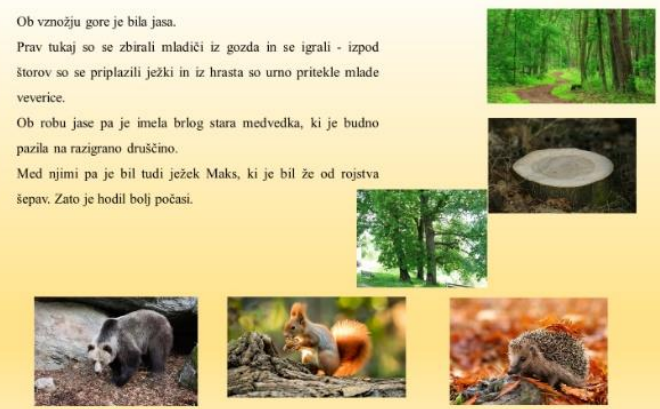

Nacnkrat je bila jasa prazma. Stara medvedka je hotela izkoris rlogu. P. done

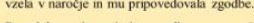

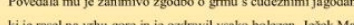
kije rasel na vithu gore in je odravil vaskik
si je to zgoodbo se poscbej dobro zapomnil
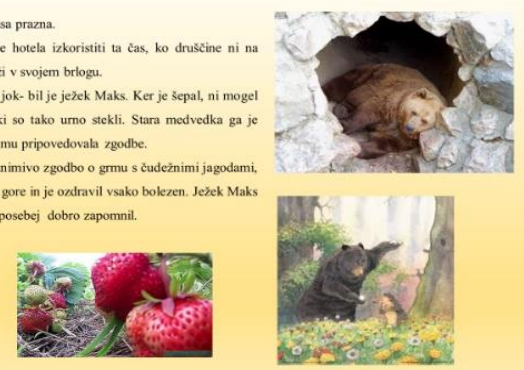

Ježck Maks se je spomnil, kako dobra je bila medvedka do njih.

Odbớl se je, da pojde na goro.

Pot je bila zahtevna in na smrt ga je bilo strah. Na vrhu je nasel grm, na katerem je bila le še cna sama jagoda. Odtrgal joje in tekel v dolino kot se nikoli

Medvedki so medtem pesale moči. Vevericke pa so točile dechele solze, ker niso vedele, kako bi ji pomagale Nenadoma se odpro vata - bil je Maks v spremstvu ostalih jêkkov. In v trenutku, ko je stara medvedka

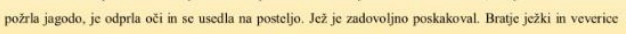
so ga cudno gledali. Maks je sele tedaj opazil, da ne sepa vec in da je tudi on ozdravel.

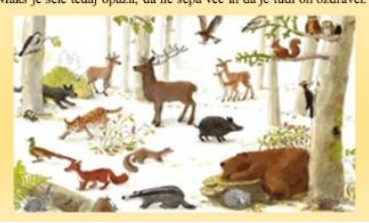

Picture 2

After reading the story, we talk, followed by a presentation of a learning topic on long and short tones. Pupils learn short and long tones through the song Albince Pesek "Ples". After listening to the song, we talk to the students about it.

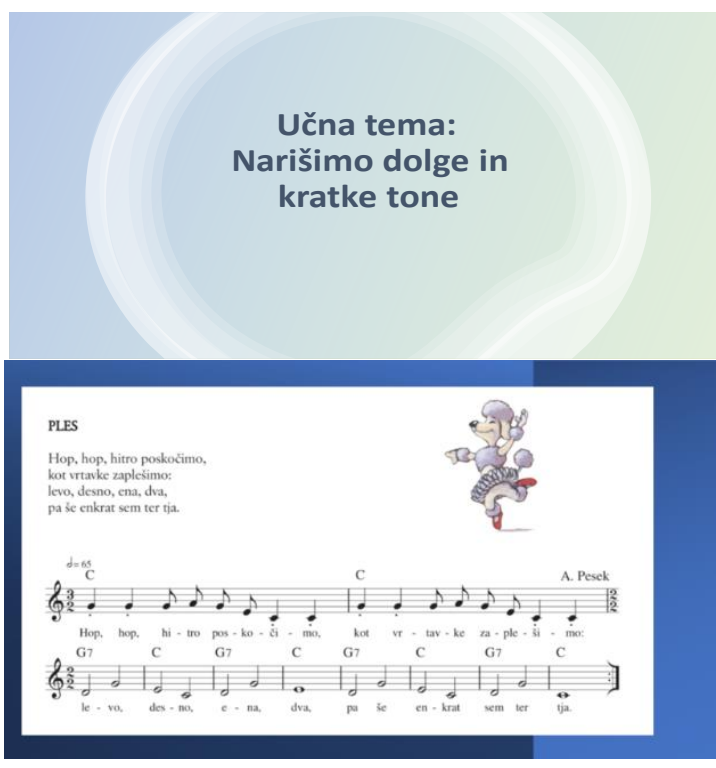

Picture 3

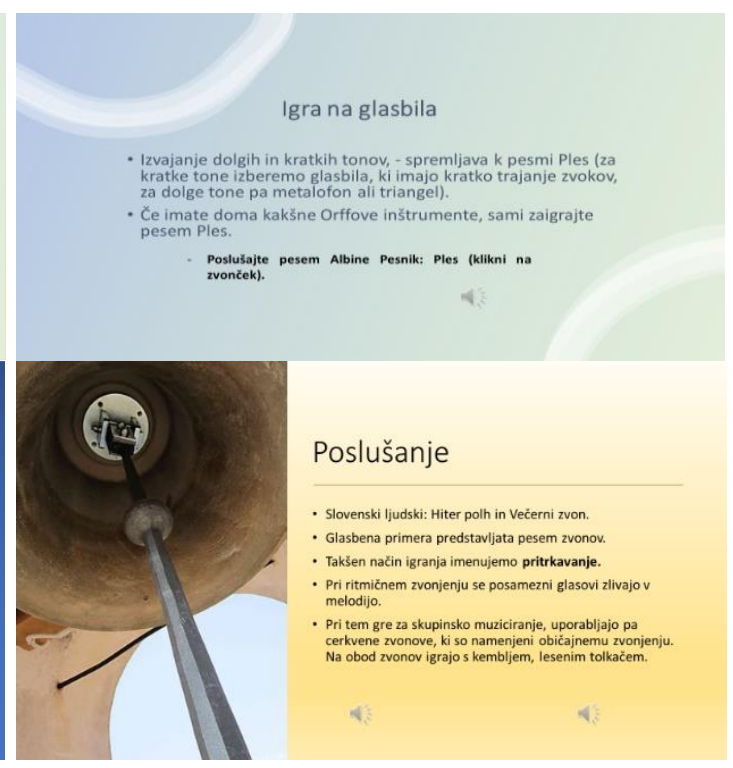

Picture 4 
Students learn what listening and tapping mean. Then they also get to know the parts of the church bell and the movement, staging long and short sounds - dancing while singing songs.

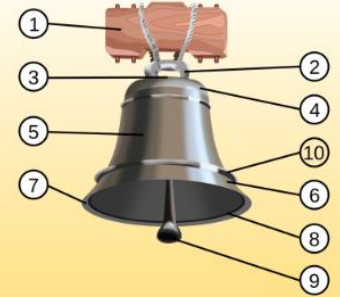

1. jarem, 2. krona, 3. glava, 4. klobuk, 5. polje, 6. udarni obroč, 7. rebro, 8. krilo, 9. kembelj, 10. bok

Picture 5
Gibanje

- Gibno uprizarjanje dolgih in kratkih zvokov - ples ob petju pesmi Ples (pri prvem delu delomo mañše in kraǰ̌̌e gibe, pridrugem pa večje in daljiše).

Zanimivo: Postusti

(120) Minutha za slasbeno teorili: Ton (112) - YouTube

(120) Glasbena britho: Tonskia abeceda (472)-YouTube

Didaktična igra: Piščanci in lisice

Namen naše ure danes bo, da se bomo malo poigraliz dolžino tonov.

Vsi veste, da nekateri instrumentizvenijo dolgo, drugi pa kratko.

Ali bi lahko gibanje različnih živali kako povezaliz dolgimi in kratkimitoni?

Lisice poznamo in vemo, da se potuhnjeno plazijo z dolgimi koraki.

Mladi piščanci pa stopicajoz drobniminožicami in pri tem delajo kratke korake.

Če bi bili v šoli, bi zaigrali naslednjo igrico:

- Pri kratkih zvokih pridejo piščanci iz kurnikov (sedijo na stolu) in plešejo okoli lisic, ki dremljejo, obenem pa pozorno poslušajo. Ko slišijo dolge zvoke, se piščanci hitro poskrijejo, lisice pa začnejo loviti; ujamejo vse piščance, ki niso dobro poslušali in se niso skrili. Ujeti piščanci postanejo lisice in igro nadaljujemo.

Glede nato, da nismo v šoli, poskusite sami zaigrati dolge in kratke tone.

- Za spremljavo bi lahko uporabili triangel in palčke, potem bi igro ponovili še z metalofonom in ksilofonom.

- V kolikor imate brate in sestre lahko skupajzaigrate prizor.

\section{Picture 7}

Then I tell the students to prepare music notebooks and to draw long and short tonnes while listening to the melody and the song.

\section{Ustvarjalnost}

- Risanje dolgih in kratkih tonov
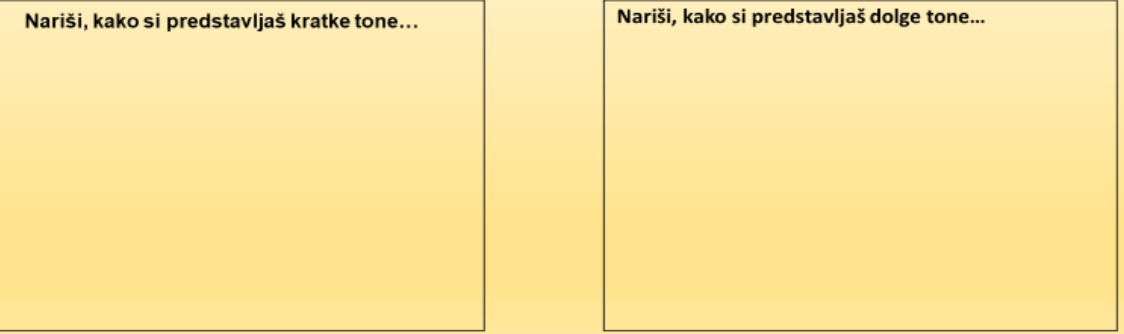

Picture 8 
When we do this, the students get to know the Macedonian song Duvna vetre razvigorče.

The song is first sung by a student from Northern Macedonia, then we listen to it on You tube (https://www.youtube.com/watch?v=p3ne4EefHXE) and try to learn it. Let us talk aboutthe translation of the song or about meaning.

\section{Makedonska pesem}

\begin{tabular}{|c|c|}
\hline & $\begin{array}{l}\text { Дувна ветре развигорче } \\
\text { Нишна гранче над изворче.(X2) }\end{array}$ \\
\hline & Дувна ветре будигора \\
\hline Златно Славејче - 1975 & Раззелени сто јавора.(X2) \\
\hline - Текст: Бошко Смаќоски & \\
\hline - Музика: Петар Сидовски & Дувна ветре развигорче \\
\hline - Аранжман: Славе Димитров & Нишна гранче над изворче.(X2) \\
\hline - Исполнува: Весна Бучкова & Дувна ветре љубопитче \\
\hline Povezava besedila: & Накитено со кокиче.(X2) \\
\hline $\begin{array}{l}\text { https://www.last.fm/music/Zlatno+Slav } \\
\text { eice//Duvna+Vetre+Razvigorce/+wiki }\end{array}$ & $\begin{array}{l}\text { Дувна ветре развигорче } \\
\text { нишна гранче над изворче.(X2) }\end{array}$ \\
\hline Povezava: & $\begin{array}{l}\text { Дувна ветре југовица } \\
\text { за зимата шлаканица.(X2) }\end{array}$ \\
\hline https://www.youtube.com/watch?v $¥ 3$ ne4EefHXE & Дувни ветре, дувни. \\
\hline
\end{tabular}

\section{Picture 9}

We enrich every hour of remote music with new songs. Pupils look forward to learning about a new song, a new culture presented by their classmates and then spreading positive energy at home. It means that they take this song home, where the locals get to know the children's school world, the world of different languages, songs, games, dances.

The school space thus becomes a field of enrichment, expansion, and integration. 1. Conclusion From theory and practical implementation, I can con We enrich every hour of remote music with new songs.

Pupils look forward to learning about a new song, a new culture presented by their classmates and then spreading positive energy at home. It means that they take this song home, where the locals get to know the children's school world, the world of different languages, songs, games, dances. The school space thus becomes a field of enrichment, expansion, and integration.

\section{Conclusion}

From theory and practical implementation, I can conclude that music is very importantto me, to every human being. It enriches and builds us in various fields. It helps us understandourselves and others, teaches us about other cultures, events and doings that build the world.We express ourselves musically in different ways, we create it in our own way; singing, dancing, musical creation is part of our being, but consciously and unconsciously we also takeon musical experiences, the practices of our surroundings. All of this enriches our experiences,connects us to our social environment, and enriches us all spiritually.

I am happy to be able to teach students something new and thus transfer my knowledge through the art of music and in the field of music art, even art in general. Pupils at school learn about art, express themselves through music, as well as artistically, verbally, through movement. Music is a universal language that has no boundaries and is spreading everywhere, in different ways. clued that music is very important to me, to every human being. It enriches and builds us in various fields. It helps us understand ourselves and others, teachesus about other cultures, events and doings that build the world. 
We express ourselves musically in different ways, we create it in our own way; singing, dancing, musical creation is part of our being, but consciously and unconsciously we also take on musical experiences, the practices of our surroundings.

All of this enriches our experiences, connects us to our social environment, and enriches us all spiritually. I am happy to be able to teach students something new and thus transfer my knowledge through the art of music and in the field of music art, even art in general. Pupils atschool learn about art, express themselves through music, as well as artistically, verbally, through movement. Music is a universal language that has no boundaries and is spreading everywhere, in different ways.

\section{Reference:}

Muršič, R. (1993). O moči glasbe. Časopis za kritiko znanosti 21 (160/161):101-124 [The power of music], Journal of the Critique of Science 21 (160/161): 101-124

Sodja L. (2006). Mladi slovenski glasbeniki v Evropi. [Young Slovenian musicians in Europe] Ljubljana: Založba Družina

Uranjek, A. (1993). Sprostitev in glasba. Psihološka obzorja 2 (3/4): 185 - 188. [Relaxation and music. Psychological horizons 2 (3/4): 185 - 188]

Taja Knez, (2020). Kaj je glasba? [What is music?] R e t r i e ve d fro m: https://tajaknez.wordpress. com/kaj-je-glasba/

MIZŠ, (2011). Učni načrt. Program osnovna šola. Glasbena vzgoja. [Curriculum. Elementary school program. Music Education] Ljubljana: MIZŠ: ZRSŠ. Retrieved from: https://www.gov.si/assets/ ministrstva/MIZS/Dokumenti/Osnovna-sola/Ucni- nacrti/obvezni/UN glasbena vzgoja.pdf 